\author{
CONSTANTIN GEAMBASU \\ (D) https://orcid.org/0000-0003-3427-4969 \\ Uniwersytet $w$ Bukareszcie \\ Bukareszt
}

\title{
Olga Tokarczuk w Rumunii
}

\begin{abstract}
Olga Tokarczuk in Romania
Abstract: The author discusses the reception of Olga Tokarczuk's works in Romania on the basis of translations, critical essays and radio and press interviews. Olga Tokarczuk is the best-known contemporary writer from Central Europe in Romania, thanks to numerous translations (almost all of her novels have been translated into Romanian, except The Books of Jacob, due to be published next year). An important role in the dissemination of her works has been played by the Polirom publishing house in Iași, which published a special series devoted to Tokarczuk. The quality of the translations of the Polish novelist's texts is also high. Particular credit for this goes to Cristina Godun, a specialist in Polish Studies, who has managed to render the peculiarities of Tokarczuk's narrative and style in Romanian. The paper also briefly discusses the difficulties encountered during the translation of Tokarczuk's texts.
\end{abstract}

Key words: Reception, translation studies, intertextuality

Olga Tokarczuk zadebiutowała w 1993 roku. Kilka lat później wydawnictwo Polirom opublikowało w ramach serii „Trzecia Europa”, poświęconej powieści środkowoeuropejskiej ${ }^{1}$, Călătoria oamenilor Cărții [Podróż ludzi Ksiegi]. Powstanie serii zainicjowała grupa młodych nauczycieli akademickich z Uniwersytetu w Timişoarze, wspierana przez profesorów Adrianę Babeți i Cornela Ungureanu. Pamiętam, że sam zadzwoniłem do Olgi Tokarczuk i otrzymałem zgodę na tłumaczenie. Ukazanie się książki w 2001 roku zbiegło się w czasie z otwarciem Instytutu Polskiego w Bukareszcie. Dyrektor Instytutu Roland Chojnacki, absolwent filologii rumuńskiej Uniwersytetu

${ }^{1} \mathrm{~W}$ ramach tej serii ukazały się też powieści: Prawiek $i$ inne czasy Olgi Tokarczuk (przeł. O. Zaicik), Dolina Issy Czesława Miłosza (przeł. O. Zaicik i S. Velea), Poczqatek Andrzeja Szczypiorskiego oraz Moja Europa Jurija Andruhowycza i Andrzeja Stasiuka (przeł. C. Geambaşu). 
im. Adama Mickiewicza w Poznaniu, od razu nawiązał kontakty z różnymi instytucjami kultury i osobami zaangażowanymi w promocję literatury i kultury polskiej. Sfinansował również tłumaczenie i zorganizował promocję książki. Było to wyjątkowe wydarzenie, ponieważ została na nie zaproszona Olga Tokarczuk. Za sprawą przyjęcia przygotowanego przez Ambasadę RP w Bukareszcie pisarka po raz pierwszy zetknęła się z Rumunią, wtedy też nawiązała kontakty z miejscowymi poetami i pisarzami. Dzięki temu spotkaniu Rumunia otworzyła swoje podwoje przed Olga Tokarczuk, co pozwoliło autorce później wielokrotnie odwiedzać nasz kraj. W następnym roku w tej samej serii wydawniczej ukazał się Străveacul şi alte vremi [Prawiek i inne czasy] w doskonałym tłumaczeniu nieodżałowanej Olgi Zaicik, co zwiększyło zainteresowanie czytelników rumuńskich prozą młodej pisarki. W 2012 roku Wydawnictwo Art opublikowało przetłumaczoną przez Cristinę Godun powieść Rătăcitorii [Bieguni], którą zaprezentowano na spotkaniu autorskim w księgarni Bastilia w Bukareszcie. Uczestniczyli w nim zarówno czytelnicy, jak i krytycy literaccy. Zadano wiele pytań autorce i tłumaczce, a żywa dyskusja wieńcząca spotkanie przyniosła zapewne lepsze zrozumienie tekstu. W listopadzie 2015 roku na targach książki Gaudeamus w Klużu wydawnictwo Casa Cărții zorganizowało promocję kolejnej książki w tłumaczeniu Cristiny Godun Casă de zi, casă de noapte [Dom dzienny, dom nocny], która przełożyła także inne dzieła polskiej prozatorki na język rumuński. W następnych latach wydawnictwo Polirom, jedno z najbardziej znanych i renomowanych w kraju, sukcesywnie pozyskiwało prawa autorskie i publikowało pozostałe książki Olgi Tokarczuk: Ultimele povestiri [Ostatnie historie], Rătăcitorii [Bieguni] oraz Poartă-ți plugul peste oasele morților [Prowadź swój pług pržez. kości umarlych]. Ostatnia powieść polskiej noblistki, Ksiegi Jakubowe, która przyniosła jej kilka prestiżowych międzynarodowych nagród i została przetłumaczona na kilkanaście języków, ukaże się w Rumunii w przyszłym roku.

Na III Światowym Kongresie Tłumaczy Literatury Polskiej zorganizowanym przez Instytut Książki w 2007 roku Olga Tokarczuk była gościem honorowym. W wystąpieniu otwierającym wydarzenie podziękowała tłumaczom i podkreśliła ich istotną rolę w promocji dzieł literackich. Już wtedy pisarka była w grupie tych polskich autorów, których książki są tłumaczone na świecie (dziś jej utwory można przeczytać w ponad 40 językach). Zdając sobie sprawę z wagi pracy, którą wykonuja tłumacze, Olga Tokarczuk od początku swojej działalności pisarskiej utrzymywała z nimi dobre stosunki i wykazywała się niezwykłą otwartościa, odpowiadając na pytania mające rozwiązać trudności pojawiające się w procesie translacji. 


\section{Referaty, artykuły, szkice}

Przekład utworu tłumacze zwykle opatruja przedmową lub posłowiem, które mają ułatwić czytelnikom zrozumienie tekstu literackiego oraz jego kontekstu kulturowego i historycznego. Przedmowa, którą napisałem do dzieła Călătoria oamenilor Cărții [Podróż ludži Ksiegi], omawiała kilka specyficznych cech struktury tekstu, a także stylu Olgi Tokarczuk. Wskazywałem w niej między innymi na rolę elementów związanych z inicjacją, magia, alchemią, cudem, mitem i legendą, które od początku lektury budują nastrój pełen romantycznych konotacji.

Motyw podróży, kluczowy w dotychczasowej twórczości pisarki, obrazują najróżniejsze postacie: wędrowiec, podróżnik, misjonarz, odkrywca i turysta. Wśród bohaterów przeważaja jednak duchowi pielgrzymi, którzy są nie tyle zainteresowani dotarciem do celu, co ścieżką, droga, planem wyprawy. Podróż wiąże się z głębokim doświadczeniem przemijania, zmiany i oderwania się od szczegółów. W pierwszej powieści Księga nabiera symbolicznego znaczenia: stanowi element integrujący poprzez swoją świętość i mądrość, źródło umożliwiające rozszyfrowanie zagadki życia, poetycki opis rzeczywistości, obraz doskonałego i stabilnego świata, obietnicę zmiany. Droga staje się z kolei prawdziwą przygoda inicjacji i poznania, zrozumienia ludzkiej kondycji. Koncepcja artystyczna zasadza się tu w dużej mierze na antynomiach: natura - kultura, metafizyka - empiryzm, nauka - magia, życie śmierć, ograniczenie - bezkres. Bogaty antynomiczny świat powieści ujawnia zainteresowania młodej pisarki filozofia, alchemią, magia i metafizyka, otwierając w ten sposób perspektywę refleksji nad relacją między człowiekiem a boskościa, światem widzialnym i niewidzialnym. Eros, kolejny ważny element strukturalny utworu, pozwala na ujawnienie złożonego związku między ciałem a duszą. Szczegółowo przeanalizowałem opisane w książce odmiany miłości i podkreśliłem wkład Olgi Tokarczuk w „psychologiczne przemyślenia na temat relacji międzyludzkich i uchwycenie stereotypów dominujących dotychczas w tej sferze" (Geambașu 2002, 14-15). Na kartach powieści ujawniają się upodobania pisarki do mitologizowania. Autorka odwołuje się do prastarych mitologii, w których pojawiają się smoki lub anioły, świata cudownego jak w bajkach, noszącego znamiona mitycznego wszechświata zarówno za sprawą wyglądu krajobrazu, jak i obecności demonicznych istot. Jednak - w przeciwieństwie do bajki - koniec Podró̇yy ludzi Ksiegi jest smutny. Tylko Gauche, głuchoniemy chłopak, dociera do Księgi, ale nie 
potrafi odczytać żadnego z jej znaków. Mimo to, dotknąwszy Księgi, Gauche odzyskuje mowę, tak więc będzie mógł przekazać, że widział, iż Księga naprawdę istnieje, co oznacza, że droga nie była daremna, a człowiek będzie mógł kontynuować wędrówkę. Stworzona w duchu romantyzmu pierwsza powieść Tokarczuk ujawnia przywiązanie pisarki do konwencji romantycznej ściśle związanej z tradycją ludowa, folklorem, wierzeniami, bajkowością i mitologia. Taki sposób tworzenia tekstu widoczny jest w kolejnych jej utworach.

Drugim szkicem w języku rumuńskim dotyczącym twórczości Tokarczuk jest posłowie zamieszczone w książce Străveacul şi alte vremi [Prawiek $i$ inne czasy]. Jego autorka Olga Zaicik podkreśla przede wszystkim problematykę cudu spowijającego otaczające nas rzeczy. Cud leży u podstaw „rodzącego się świata, który posiada wszystkie cechy prawdziwego życia, trwa przez określony czas, potem rozpada się i umiera. Życie i śmierć tak się ze sobą przenikaja, że nie można ich rozdzielić. Tym, co ratuje je od niebytu, a więc od zapomnienia, jest właśnie cud" (Zajicik 2002, 281-282).

Prawdziwe znaczenie konkretnego świata nie jest w pełni odgadnione, „przedmioty, przyroda i ludzie Prawieku przekornie zachowują swoją tajemnicę” (Zajicik 2002, 275). Nad tym światem unosi się nieuchronny „,znak rozkładu", a więc nieuniknionej śmierci. Tłumaczka zwraca uwagę na dziwne, niezwykłe losy i egzystencje, niespotykane nigdzie indziej. Widać to szczególnie w historiach dwojga bohaterów, Izydora i Kłoski, którzy „należą wyłącznie do Prawieku, jak i w skłonności do bajkowości” (Zajicik 2002, 277). Oprócz tych dziwnych postaci w powieści występują także istoty znane z lokalnego folkloru (Zły Człowiek i Topielec Pluszcz), a także anioły, Matka Boska i sam Bóg. Prawiek $i$ inne czasy to nie „tylko wszechświat ludzi”, ale także natury (to miejsce, gdzie rosną grzyby, jest sad, w którym rosną jabłonie i grusze, róże, lipy). W splocie tekstu stale widoczne jest „wyraźne i celowe mieszanie przestrzeni i czasu, rzeczywistości i snu, które nie tylko się ze sobą splataja, ale także nakładają się na siebie" (Zajicik 2002, 280) - jest to chwyt literacki z upodobaniem stosowany przez pisarkę. Wszechświat ludzi składa się również z przedmiotów mających swój odrębny długotrwały byt (Zajicik 2002, 281). Na podstawie analizy tekstu tłumaczka dochodzi do wniosku, że Prawiek staje się „księgą ostatecznych poszukiwań i rozwiązań”, znajdującą się „na granicy cudu i rzeczywistości, przestrzeni i czasu” (Zajicik 2002, 282).

W 2003 roku z inicjatywy Instytutu Polskiego oraz Rumuńskiego Instytutu Kultury zorganizowano międzynarodową konferencję poświęconą polsko-rumuńskim stosunkom kulturalnym, podczas której profesor Antoaneta 
Olteanu wygłosiła odczyt Dimensiunea mitologică în romanele Olgăi Tokarczun [Wymiar mitologiczny w powieśsiach Olgi Tokarczuk] (Olteanu 2006)2. Wychodząc od konstatacji poczynionych przez Mirceę Eliadego $(1978,72)$ i Leszka Kołakowskiego (1981) w badaniach nad mitem ${ }^{3}$, autorka formułuje ciekawe stwierdzenia dotyczące magicznych i twórczych zdolności bohaterów Prawieku, ale także Podrósy ludzi Ksiegi. Podkreśla m.in. złożoność kreacji opartej wielokrotnie na „zasadzie gry, na regułach przejawiajacych się we śnie”, a nawet na „manipulowaniu ludźmi przez bóstwo” (Olteanu 2006, 57). Zarysowują się w ten sposób światy nałożone, twory na poziomie indywidualnym, które - w przeciwieństwie do kreacji Demiurga - znajduja się „pod znakiem degradacji”. Postacie nie maja podejścia integrującego, przeciwnie: ich wielorakie wizje są niepełne. Świat - mówi autorka artykułu - jest postrzegany niczym młyn mielący odczucia, obserwacje, wyobrażenia, z których składa się życie.

Kolejny fragment tekstu Olteanu koncentruje się właśnie na kreacji jako grze, jako śnie, co przypomina teksty innego wybitnego twórcy, mianowicie Brunona Schulza (Geambaşu 2010). Prawiek dostarcza materiału na nowe twory, aby móc przezwyciężyć codzienność, staje się „mitycznym centrum świata" (Olteanu 2006, 60). Z kolei sen to przedłużenie prawdziwego, konkretnego życia, a oniryzm ujawnia się w kreacji niemal wszystkich bohaterów powieści (Olteanu 2006, 62). Dążność pisarki do tworzenia pewnej mitologii jest podkreślana poprzez powtarzanie zwykłych, rutynowych gestów o uogólniającej wartości, za których sprawa powstanie model i sens jakiegoś mitycznego świata (Kołakowski 1981, 14).

W wywiadzie dotyczącym twórczości Olgi Tokarczuk, wyemitowanym 11 X 2019 roku w Radio România Cultural, pisarka Simona Sora przypomniała między innymi, że Prawiek jest „konstrukcją wyjątkowa, rodzajem biblii, światem stworzonym prawie z niczego, bez jakiejkolwiek teorii, tkająca historie do samego końca, bez obłudy, bez »współpracy« z czytelnikiem za plecami powieści, bez porozumiewawczego puszczania oka do czytelnika"4.

Mniejszym zainteresowaniem czytelników cieszyła się książka Casă de ži, casă de noapte [Dom džienny, dom nocny], opublikowana przez wydawnictwo Ca-

\footnotetext{
2 Referat został opublikowany w 2006 roku w czasopiśmie "Romanoslavica".

3 Zob. też przekład rumuński: Kołakowski L., Prę̧ența mitului, București 2014.

${ }^{4}$ Wywiad Timpul prezent în literatură - Cu și despre Olga Tokarczuke, laureata Premiului Nobel pentru Literatură dostępny na stronie internetowej radia (tłum. własne) - https://www.mixcloud. com/RadioRomaniaCultural/timpul-prezent- $\% \mathrm{C} 3 \%$ AEn-literatur $\% \mathrm{C} 4 \% 83$-cu- $\% \mathrm{C} 8 \% 99 \mathrm{i}$-des pre-olga-tokarczuk/ [dostęp: 6.12.2019].
} 
sa de Știință w 2015 roku. Utwór nie doczekał się recenzji ani artykułów krytycznych. Dopiero w październiku 2019 roku, w związku z przyznaniem Oldze Tokarczuk Nagrody Nobla, ukazała się kronika autorstwa Rodicy Grigore (Grigore 2019), w której oprócz informacji biograficznych o pisarce znajdujemy uwagi dotyczące struktury i tematyki dzieła Dom drienny, dom nocny. Grigore podkreśla, że wszystkie opowiadania łączy jednolita koncepcja estetyczna: „Życie ludzkie ma niezliczone aspekty, wbrew wszelkim próbom niemożliwe jest zdefiniowanie ich do końca" (Grigore 2019). Stąd zachwiana granica między rzeczywistością a wyobraźnią, płynna substancja narracji została zbudowana przede wszystkim przy użyciu wspomnień i sugestii. Technika narracyjna - dodaje Rodica Grigore - bazuje „na ironii, oralności i specyficznej tematyce”, podkreśla „znaczenie ludzkich zbiorowości, zwłaszcza w wiejskich lub odizolowanych regionach Polski (i nie tylko); należąc do społeczności, człowiek może naprawdę stawić czoła wielkim wyzwaniom historii - często okrutnym i niesprawiedliwym" (Grigore 2019). Rodica Grigore zwraca uwagę na pewną osobliwość prozy Olgi Tokarczuk, a mianowicie to, że czynnikiem, który bardzo mocno wpływa na los i zachowanie jednostki, jest historia (to np. losy Polaków deportowanych ze wschodnich terenów zajętych przez Związek Radziecki i przesiedlonych po II wojnie światowej na Śląsk lub Pomorze). Opisane wydarzenia ujawniaja drastyczna prawdę: „Człowiek jest zwykłym trybikiem poddawanym działaniu wielkich mechanizmów historii" (Grigore 2019). Niepokojące przesłanie uzasadnia w dużej mierze wielorakość szczegółów, jakie Olga Tokarczuk stawia przed czytelnikiem, a także znaczenie fragmentu jako chwytu literackiego: „Tylko przez nakreślenie najważniejszych szczegółów życia wszystkich osób w tej miejscowości można zrozumieć prawdę o ich istnieniu, ale także tragizm, z którego składa się życie codzienne, poza komicznym pozorem zdarzeń lub sytuacji” (Grigore 2019). Tak więc mozaikowa struktura książki pozwala na uchwycenie ,szerokiego zakresu ludzkich doświadczeń (...), wyzwań, przed którymi stoją prości ludzie, często w obliczu bezlitosnych sił historycznych lub społecznych" (Grigore 2019). Pozornie banalne czynności nabieraja - wraz z rozwojem narracji i opowieści - charakteru wielkich tajemnic istnienia. Rzeczy zwykłe lub mniej znaczace, istoty marginalne, niosą w sobie znaczący ładunek metafizyczny, częstokroć tragiczny, zmuszający do refleksji.

Simona Sora we wspomnianym wywiadzie zwraca z kolei uwage na perspektywę narracyjną: spojrzenie pada na człowieka, którego mamy przed soba. Jest to podstawowa technika, niezbędna w dotarciu do wnętrza drugiej 
osoby. Powieść Dom dzৃienny, dom nocny podkreśla związek między tożsamością a innością w bogatym, konkretnym i psychologicznym kontekście.

Książka Rătăcitorii [Bieguni] wzbudziła żywe zainteresowanie rumuńskich odbiorców. Cristina Godun, tłumaczka utworu, napisała szkic, który precyzyjnie oddaje istotę narracji Olgi Tokarczuk (Godun 2013). Godun uważa, że „centralnym wątkiem książki jest podróż” postrzegana w różnych hipostazach: ,jako zjawisko kultury, sposób poznania prawdy, życia, odwołania się do ludzkiej kondycji, jako sposób buntu, szukania ratunku, jako syndrom" (Godun 2013, 119). Przywołanie motywu peregrynacji jasno wynika z tytułu książki: jest to symbol, metafora, parabola („wszyscy jesteśmy nomadami, rodzajem współczesnych wędrowców”; Godun 2013, 121). Podróż - mówi tłumaczka - jest motywem nie tylko literackim, ale też antropologicznym, kulturowym, społecznym, przypowieścią o życiu i drodze. Ruch jest celem samym w sobie. Tokarczuk zakłada, że stagnacja, bezruch, a nawet wykorzenienie są prawdziwymi zagrożeniami dla współczesnego człowieka, burzącymi jego wewnętrzny spokój i iluzoryczną stabilność. Podróż oznacza także „poszukiwanie na zewnątrz równowagi, poszukiwanie siebie i celu w życiu" (Godun 2013, 123). Całościowo tekst jest obrazem współczesnego człowieka, który jest hiperaktywny, wykorzeniony, niespokojny. Cristina Godun poddaje pod dyskusję także formę powieści (powieść konstelacja, monografia pewnego zjawiska, proza poetycka, przeplatana naukowymi fragmentami). Podążając za rozwojem narracji, jej fragmentaryczna, pozornie chaotyczną struktura, tłumaczka stwierdza, że „Olga Tokarczuk jest naprawdę mistrzynią gawędziarstwa” (Godun 2013, 123), choć moim zdaniem takie stwierdzenie wymaga lepszego uzasadnienia.

W wywiadzie udzielonym Adeli Greceanu ${ }^{5}$ Olga Tokarczuk omawia strukturę Biegunów: „Starałam się porzucić tradycyjny porządek przyczynowo-skutkowy, powiązać ze sobą opowiadane wątki i historie w sposób zupełnie inny: poprzez skojarzenia, refreny, powtórzenia. Ja nazywałam sobie te wszystkie sposoby połączeń takimi technicznymi terminami, jak spawy, mostki, śruby"6. Dzięki zastosowaniu takiej techniki prozaiczka odkrywa

5 Olga Tokarczuk przyjechała do Bukaresztu w kwietniu 2013 roku, aby promować swoja powieść Bieguni. Wystapiła na żywo w Radio România Cultural, w programie „Timpul prezent", zrealizowanym przez Adelę Greceanu.

${ }^{6}$ Wywiad Timpul prezent în literatură - Cu și despre Olga Tokarczuk, laureata Premiului Nobel pentru Literatură dostępny na stronie internetowej radia (tłum. własne) - https://www.mixcloud. com/RadioRomaniaCultural/timpul-prezent- $\% \mathrm{C} 3 \%$ AEn-literatur $\% \mathrm{C} 4 \% 83$-cu- $\% \mathrm{C} 8 \% 99 \mathrm{i}$-des pre-olga-tokarczuk/ [dostęp: 6.12.2019]. 
wewnętrzne ,ja” bohaterów, co sprawia, że czytelnicy nie patrzą na nich jak na obcych. Jest to spojrzenie szczere, naturalne, „bez refleksji, bez osądu i bez sentymentu" (Godun 2018, 190), jak pisze Tokarczuk w utworze Dom dzienny, dom nocny.

Ostatnim historiom, książce o dobrze zbudowanych strukturach narracyjnych, tłumaczka Cristina Godun, poświęciła osobny szkic analityczny (Godun 2018). Los trzech kobiet - Parki (babci), Idy (córki) i Mai (wnuczki) odgrywa decydującą rolę w kształtowaniu narracji. Jak stwierdza Godun, polscy krytycy analizowali narrację głównie przez pryzmat fenomenologii śmierci, nawiązując do fascynacji pisarki tanatologia, mistycyzmem i mitologia (Godun 2018, 190). Trzy postaci żeńskie odznaczają się „,bogatym światem wewnętrznym i dobrze zdefiniowaną filozofia życia”, ewoluując w niemal matriarchalnym wszechświecie. „Męskie postaci powieści są raczej rekwizytami w biografiach bohaterek i narracji (...) i ukazane są karykaturalnie, w sposób zdeformowany, ironiczny" (Godun 2018, 191). Tłumaczka zestawia różne postawy trzech bohaterek w obliczu śmierci. Ida przeżyła wypadek samochodowy i ocenia swoje życie z perspektywy człowieka, który otarł się o śmierć, otrzymując od życia drugą szansę, równoznaczną z duchowym odrodzeniem. W jej wizji śmierć jawi się jako „konieczność zachowania równowagi życia" (Godun 2018, 193), jest to nie tylko proces biologiczny, ale także zjawisko kulturowe, społeczne, duchowe i dydaktyczne. Dla Parki śmierć ma raczej wymiar biologiczny, indywidualny. „Nie jest jej obca, ale nie jest jej też bliska”. Śmierć jest „podróżą pionową, w duchowej przestrzeni własnego bytu i boskości” (Godun 2018, 195). Maja, poszukując równowagi i sensu życia, stara się odsunąć od siebie perspektywę śmierci, przemieszczając się, podróżując lub uciekając w rzeczywistą lub wyobrażoną przestrzeń. Stary mag z trzeciej części książki, „doskonały mistrz złudzeń”, demaskuje Maję, demistyfikuje jej spojrzenie na rzeczywistość, a śmierć przestaje być dla niej złudzeniem (Godun 2018, 198). Przeprowadzona analiza prowadzi ostatecznie do wniosku aksjologicznego: „Olga Tokarczuk (...) wprowadza do literatury zagadnienia życia codziennego, które - chociaż banalne - na kartach jej powieści ulegają uszlachetnieniu, stając się cennymi tematami literackimi, a nie prozaicznymi obrazami życia" (Godun 2018, 198).

Z kolei Gabriela Adameșteanu w artykule opublikowanym w czasopiśmie „Observator Cultural” po przyznaniu Oldze Tokarczuk Nagrody Nobla twierdzi, że Ostatnie historie „tworzą dobrze zbudowany tekst dzięki trzem obszernym sekwencjom, subtelnie ze sobą połączonym poprzez narrację, 
a przede wszystkim przez niezwykłą atmosferę". Podkreśla także obecność przyrody ze swym „nieco złowrogim pięknem” i „melancholijnym witalizmem" (Adameșteanu 2019, 23). Zauważa również wielowarstwowość znaczeniową ksiażki, jej „ukrytą poezję”, „stylistyczną oryginalność i niezwykłą głębię pisarki” (Adameșteanu 2019, 23).

Poartă-ți plugul peste oasele morților [Prowadŕ swój plug prz̨ez kości umarlych] książka, która w Rumunii ukazała się kilka miesięcy przed przyznaniem pisarce Nagrody Nobla, spotkała się z dużym uznaniem odbiorców. Cristina Godun podkreśla „etyczno-filozoficzny wymiar powieści”, zawarty w ,autentycznej obronie dwoistości świata, w którym dobro i zło są równie niezbędne dla rozwoju i kondycji człowieka" (Godun 2019). Powieść, określona przez tłumaczkę jako „thriller moralny i egzystencjalny”, jest także sygnałem ostrzegajacym przed „ekscesami, okrucieństwem i przemocą współczesnego człowieka”, „medytacją o współczuciu i prawie do istnienia wszystkich stworzeń” (Godun 2019). Przekraczając granice różnych gatunków literackich, Tokarczuk zmierza w kierunku literatury ambitnej, zajmującej się głównymi problemami współczesnego świata. Na końcu artykułu tłumaczka stwierdza, że powieść stanowi „emocjonalną wypowiedź o współczuciu i człowieczeństwie" (Godun 2019) uzupełniającą bogaty obraz jej prozy.

Po przyznaniu Oldze Tokarczuk Nagrody Nobla prasa literacka w Rumunii zareagowała natychmiast. W czasopiśmie „Obervator Cultural” pojawiły się trzy artykuły. O tekście Gabrieli Adameșteanu już wspomniałem. Autorką drugiego jest Camelia Dinu, która nakreśliła ewolucyjne linie życia i twórczości polskiej autorki, wskazując także na pewne szczególne cechy pisarstwa noblistki, takie jak dynamizm (kompozycji, intrygi, postaci, ogólnej wizji), który powoduje fragmentację narracji i wprowadza kalejdoskopowa wizję rzeczywistości. Inną cechą charakterystyczną twórczości Tokarczuk jest zastosowanie różnych stylów i gatunków epickich, takich jak: baśń filozoficzna, opowieść policyjno-ekologiczna, powieść metafizyczna, powieść historyczna, thriller quasi-sentymentalny, bildungsroman itp., stąd niejednorodny język artystyczny o zróżnicowanym tonie i zmiennej tematyce. Większość tekstów Olgi Tokarczuk mówi o końcu ludzkiej egzystencji, która często jest pozbawiona logiki. Dinu omówiła także inne aspekty, które przyczyniły się do przyznania Polce Nagrody Nobla - lauru w pełni zasłużonego (Dinu 2019, 22).

W trzecim artykule - tym razem napisanym przeze mnie - zaznaczam, że proza Olgi Tokarczuk oscyluje między światem racjonalnym i intuicyjnym, między mityzacją i demityzacja, zaklęciem i odczynianiem świata. Przejawia- 
jąc szczególne zainteresowanie niewidzialną stroną świata, jego obliczem fantastycznym i zagadkowym, autorka jest przekonana, że pisanie pozwala na przenikanie do pierwotnych, autentycznych warstw świata, stanowiących istotę opowieści. Świat nabiera kształtu wielowarstwowego opowiadania zaskakującego bogactwem i niezwykłością (Geambaşu 2019, 22-23).

Tygodnik „România literară” odnotował przy tej okazji główne etapy literackiej podróży, którą odbyła autorka, poczynając od pierwszych opowiadań opisujących najbliższe okolice, region dolnośląski, przez powieść Bieguni, a kończąc na Prowadź swój plug przę kości umarlych. Cristian Pătrășconiu, znawca polskich realiów kulturowych, zwraca uwagę między innymi na wizję literatury Olgi Tokarczuk mającej na celu: wzbudzanie wątpliwości czytelników, zachęcanie ich do zadawania pytań, mówienie o tym, co jest mniej oczywiste. Literatura powinna prowokować do myślenia (Pătrășconiu 2019).

Oprócz tłumaczeń i tekstów krytycznych ważną rolę w popularyzacji twórczości pisarki stanowią wywiady udzielane przez nią przy różnych okazjach w prasie lub radiu. Rozmowy te przeprowadzili m.in.: Gelu Diaconu, Ema Cojocaru, Adela Greceanu i Simona Sora. Do wzrostu popularności przyczynił się też oczywiście laur noblowski. Rumuńscy czytelnicy czekaja na tłumaczenie Ksiag Jakubouych, prawdziwej epopei, przybliżającej przestrzeń Europy Środkowo-Wschodniej.

\section{Wyzwania dla tłumaczy}

Cristina Godun, doskonała tłumaczka Olgi Tokarczuk na język rumuński, z pewnością mogłaby poczynić ważne spostrzeżenia dotyczące problemów, z jakimi zetknęła się podczas przekładu. Na takie pytanie, zadane przez dziennikarzy, odpowiedziała między innymi, że nie napotkała szczególnych trudności na poziomie stylu, jednak na poziomie leksykalnym konfrontowała się z problemami równoważności w języku rumuńskim nazw różnych gatunków grzybów, owadów, roślin, elementów anatomicznych itp. Wyzwanie stanowiło także tłumaczenie tytułu Bieguni. Rătăcitorii (Wedrowcy), tytuł wersji rumuńskiej - jak twierdzi tłumaczka - nie oddaje jednak religijnej konotacji polskiej nazwy. Z kolei ja, tłumacząc Podróż ludzi Ksiegi, też miałem kłopot z oddaniem tytułu, który zachowałem jednak jak w oryginale w postaci dopełniaczowej, chociaż w języku rumuńskim często występuje wyrażenie om de carte ('człowiek zainteresowany książką pod względem naukowym; uczo- 
ny, erudyta'), jednak nie o to przecież chodzi w powieści. Użycie w tytule wielkiej litery sugeruje, że mowa o ludziach szukających szczególnej, „fundamentalnej Księgi”, dlatego tė̇ utrzymałem pisownię oryginalną (Călătoria oamenilor Cărții).

Sądzę, że trudności związane z tłumaczeniem utworów Olgi Tokarczuk są spowodowane przekraczaniem przez pisarkę gatunków literackich oraz granicy między konkretem a wyobrażeniem. Podróż lub podróżowanie w różnych kierunkach i przestrzeniach zmusza tłumaczy do ciagłego poszerzania własnych horyzontów kulturowych i historycznych. Chociaż wydaje się, że fraza nie jest skomplikowana, na poziomie leksykalnym przechodzi z jednej dziedziny do drugiej, z jednego tematu do innego, z jednego rejestru do kolejnego, co wymaga dogłębnej znajomości języka ojczystego. Tłumacze potrzebują również solidnej wiedzy z zakresu psychologii, filozofii, anatomii, biologii, a także religii. Akcent za każdym razem pada nie tyle na formę, co na obraz, na wiedzę, na rozgraniczenie i kontrolę obszarów mniej uczęszczanych. Nie możemy zapominać o stwierdzeniu z powieści Bieguni, które brzmi jak rodzaj „artystycznego credo”: „Mój zespół objawów polega na tym, że pociąga mnie wszystko, co popsute, niedoskonałe, ułomne, pęknięte. Interesują mnie formy byle jakie, pomyłki w dziele stworzenia, ślepe zaułki. (...) Wszystko, co odstaje od normy” (Tokarczuk 2007, 22).

Te słowa powodują, że tłumacz musi być zawsze ostrożny, mając do czynienia z nieprzewidywalnym tekstem. To podstawowa różnica między pracą pisarza i tłumacza, ponieważ pierwszy podąża własnymi ścieżkami, które tylko on zna lub odkrywa, drugi zaś jest „,skazany” na podążanie za pisarzem krok w krok, nawet jeśli ścieżki te nie są mu bliskie lub wręcz nieznane. Rola zarazem wspaniała, jak i niewdzięczna.

Dzięki temu, że prawie wszystkie książki Olgi Tokarczuk zostały przetłumaczone, pisarka jest rozpoznawalna na rumuńskim rynku wydawniczym. Z pewnością Nagroda Nobla przyczyni się do zwiększenia liczby czytelników jej książek. Natomiast jeśli chodzi o krytyczny odbiór tego bogatego i oryginalnego dorobku, to wszystko pozostaje w gestii nie tylko polonistów, ale także innych badaczy rumuńskich.

\section{Literatura}

Adameșteanu G., 2019, "Ultimele povestiri” ale Olgăi Tokarczuk, "Observator Cultural”, nr 991. Dinu C., 2019, A meritat Olga Tokarczuk Premiul Nobel?, "Observator Cultural", nr 991. Eliade M., 1978, Aspecte ale mitului, București. 
Geambașu C., 2001, Przedmowa, în: Tokarczuk O., Călătoria oamenilor Căr̦ii [Podróż ludzৃi Ksiegi], Iaşi.

Geambașu C., 2010, Bruno Schulz în căutarea valorilor mitice, în: Geambașu C., Ipostaze lirice și narative, București.

Geambașu C., 2019, La graniţa dintre rațional şi intuitiv, "Observator Cultural”, nr 991.

Godun C., 2013, Rătăcitorii. Călătoria ca modus vivendi, în: Olteanu A., volum coordonat, Omagiu profesorului Constantin Geambașu la 65 de ani, București.

Godun C., 2018, Ipostaze ale eului feminin in romanul Ultimele povestiri” al Olgăi Tokarczuk [Postaci kobiecego ,ja” w powieści „Ostatnie historie” Olgi Tokarczuk], ”Filologie Rusă”, XXXIV, nr 2.

Godun C., 2019, Pledoaria pentru umanitate a Olgăi Tokarczuk in "Poartă-ți plugul peste oasele morților", "Paragraf', https://revistaparagraf.com/pledoaria-pentru-umanitate-a-olgai-tokarczuk -in-poarta-ti-plugul-peste-oasele-mortilor/ [dostęp: 6.12.2019].

Grigore R., 2019, Între vise și oglinzi. Olga Tokarczuk \& Sžczepan Twardoch, "Viața Românească", nr 10.

Kołakowski L., 1981, Obecność mitu, Kraków.

Olteanu A., 2006, Dimensiunea mitologică în romanele Olgăi Tokarcz̨uk, "Romanoslavica", XLI.

Pătrășconiu C., 2019, 2 in 1 - (euro)Nobel 2019, "România literară”, nr 44.

Tokarczuk O., 2007, Bieguni, Kraków.

Zaicik O., 2002, Postowie, în: Tokarczuk O., Străveacul și alte vremi [Prawiek i inne czasy], Iași.

Constantin Geambașu - prof. dr, Instytut Slawistyki, Uniwersytet w Bukareszcie, Bukareszt, Rumunia.

Profesor w Instytucie Slawistyki Uniwersytetu w Bukareszcie, absolwent filologii polskiej Uniwersytetu Warszawskiego, autor 7 tomów szkiców krytycznych o literaturze polskiej oraz 70 tomów przekładów. Współautor Wielkiego słownika polsko-rumuńskiego. Członek Związku Literatów Rumuńskich (Filia Tłumaczy).

Kontakt: kgeambasu@yahoo.com 